\title{
Nutrient Improvement for Young Female Suffer from Anemia in Long Term Period Can Help to Decrease the Maternal Mortality Rate in Kupang City
}

Sabina Gero *)

*)Departement of Public Health Science, Magister Program, Nusa Cendana University, Kupang NTT, Indonesia

\begin{abstract}
Backround: The young female in Indonesia has became one of the govern's priority in reducing maternal mortality rate. This is a medium- term development plan of new president's program 2015-2019, it's called "a life cycle approach". In the" life cycle approach" young females whose are 12-18 years old and studying in high school are the target of the program. The majority of young women have problem of their nutrients.

Methods : The study method was cross-sectional, involving six vocasional schools in Kupang city and carried out 206 students. The study explore food comsumption patterns, nutrient status can affect , hemoglobin levels of the students. The students were male and female. Data collected through questionnaire food recall, microtoice, counterweight, and $\mathrm{Hb}$ Reflektometer. Statistic analysis were by deskriptive, bi-variate and odss ratio (OR)

Result : The repondent was $61,1 \%$ female and they were $16-18$ years old. The young female was anemia as $61,6 \%$. There were a significant relation between anemia with intake protein, $\mathrm{p}=0,001$. The odds ratio $(\mathrm{OR})$ between female and male was 1,03 . It meaned that young female more possible had anemia than young male.

Conclusion: The Life cycle approach to reduced maternal mortality rate was recently declared as a government's program. In the field, the fact is more young female in Kupang city was anemia. They will be married and becaming a mother two or more years later. Health profession must give attention for this group people, the young female ini Kupang city.
\end{abstract}

Keywords : Young female, anemia, maternal mortality rate

\section{INTRODUCTION}

"To improving the quality of the life of Indonesian people" is the fifth ideal in Nawacita 2014-2018, which was formulated as a national policy. In fact, this aspiration is related to health. The policy of National Middle-term Development Plan 2015-2019 said that first, accelerate the access to qualified health service for mothers, children, youth and the old. Secondly, nutrient improvement of Indonesian society. Acceleration of the Decline in Maternal Mortality and Infants Mortality Rates and Improvement of Nutrition Program in 2015-2019 able to be performed with the life cycle. The cycle of life starts from a baby and mother breastfeeding, toddlers, children of school age, teens, young adults, pregnant and the fetus, maternity and newborn baby and then return to the infant and mother breastfeeding [1,2]. Acceleration of the decline in maternal mortality and infants mortality rates program associated with the improvement in nutrition, especially teens as one of the actor who engage in the life cycle.

According to Indonesia Demografie and Health Survey on 2012, the percentage of teenagers who must be a mother or in their first pregnant $10 \%$, ever gave birth $7 \%$ and $3 \%$ is in their first pregnant. Teens who married in rural versus urban is $13 \%$ versus 6\% [4]. Teenagers are often have nutrinitional 
problems due to an imbalance between the consumption of nutrition to the adequacy of nutrition. Some sorts of teenagers with nutritional problems are desire for slim, looking good, avoid certain foods, wrong eating habits, skip breakfast time and love to eat some snacks. Teenagers with behavior of eating like this, get risk of suffering from anemia [12].

Anemia in young female is a main public health problem, with a prevalence of more than 13,9\% [17]. In the report of the Safe Motherhood Partnership Family Approach (SMPFA) the survey results in 10 districts showed that there are $57,4 \%$ girls is suffering from anemia [6]. Anemia is a state of the reduction in red blood cells or where the amount of hemoglobin in red blood cells is less. So that, the blood could not carry the appropriate number of oxygen that the body needs. The result of Basic health study in Indonesia showed that $54,5 \%$ teenagers consumed food under the minimum requirement [17]. The young female are more likely to experience anemia than the young male. Besides the young female having a bad diet program, they also get menstruation every month and tend to maintain their body in order to stay slim for beauty and some other reasons than to eat and drink. In the Department of Health program, young female given the blood supplement tablet and reproductive health education in school, as a preparation for the bride and groom. A woman ready to make a family, married and have children [2].

The maternal mortality in 2012, East Nusa Tenggara is 536/100.000 Live Brith (LB) national is $259 / 100.000 \mathrm{LB}$ [3]. The number of childbearing age (15-64 years old) women is $51,3 \%$ more than the number of men. The city of Kupang has a population of 15-19 years old girls about $51 \%$ and it is more than young men. The total of maternal mortality in the city of Kupang in 2012 is 82 per 100.000 livebirths but the amount declined from 2011. The maternal mortality rate which is still sluggish, may be associated with the high number of young women who got married and pregnant [7]. The marriage of youth in Indonesia was the second in the Southeast Asia after Cambodia [22] it is about $26 \%$. The results of Basic Health Indonesian Study [18], stated that the average age of women who involved in the early marriage in Kupang is between the age 15 to 19 years old, female was $11,7 \%$ and men was 15 to 19 years old amounted to $1,6 \%$. Kupang accounted for the cases of the youth pregnancy which is not planned. It is proved by $31 \%$ of teens in the city of Kupang were having premarital sex that continues on pregnancy, malnutrition, unsafe abortion and divorce [15].

\section{MATERIALS AND METHODS}

Teenagers are they who are in the transition period between children and adults. According to WHO, teenagers are kids between the age of 10-19 years old, divided into early teenagers (10-14 years old); middle teens (14-17 years old) and late teens (17-19 years old). In that period, female teens are trying to search for their identity (psychological changes), the maturation of reproductive organs (physiological changes) and change of cognition [21]. In Indonesia, 
teenagers are kids between the age of 10-18 years old. According to people's opinion, teens are not allowed to have a marriage, being pregnant, although their reproductive organs have changed. Early teens' reproductive organs are susceptible (10-14 years old). Beside early teens, there are also some groups of teenagers who have susceptible reproductive organ, such as teens who already being a mother, orphans, teens who already become the leader of house, teens who already have a marriage, teens with HIV AIDS, teens who are involved in the battle and free sex, teens who are victims of sexual harassment, human trafficking, gender harrasment and sexual deviation [14]. Early marriage for teens can cause bad impact for them, such as giving birth in early ages and drop out from school. It gives a serious impact for maternal health, especially for the risk of death birth $[1,2]$.

People can look through the teenagers growth stage from some aspects such as biological, psychological, social and spiritual aspects. Here are the stages from early teens, middle teens and late teens. Early teens are they who love freedom, delusion, imaginative, concern with their bodies and close to their peers. Middle teens, in the other hand, are they who try to search for an identity, want to date opposite sex, falling in love, able to think abstractly and have sexual fantasy. While for late teens, they start to know how to express themselves, how to make a friend selectively, have an identity, able to express love and able to think abstractively. Teenagers have to pass all the stages so they can become an adult who have no conflict with their environment [21].
Nutritional status is a person's condition or manifestation of nutrients in the form of specific variables [10]. It is also can be interpreted as a body condition after the consumption, the absorption of food. Food ability is very important to determine the nutritional status and problems in society. One of nutritional problems, which is related to teenagers is anemia. Someone is diagnozed with anemia if his/her hemoglobin is less than $12 \mathrm{gr} / \mathrm{dl}$, but if his/her hemoglobin is more than $12 \mathrm{gr} / \mathrm{dl}$ or in the position of $12 \mathrm{gr} / \mathrm{dl}$, the person cannot be diagnozed with anemia. Hemoglobin is the oxygen carrying compound. Oxygen is needed as an incendiary substance in the metabolic process in cells. Anemia can cause damages in brain, muscle, heart, uterus and other organs [19].

Anemia is one of public health problems that influenced young female and pregnant mom. If a pregnant mom has hemoglobin less than $11 \mathrm{gr} / \mathrm{dl}$, it can cause a problem in the muscle contraction of uterus during the process of giving birth, infants with low weight, long parturition, bleeding or infection and fetal hypoxia All these conditionshave impact for maternal mortality rate. Someone's hemoglobin has to be checked in order to know whether he/she has anemia or no; and checked someone's anthropometry, clinical, biochemical and biophysical to determine their nutritional status [12].

One of government's programs to reduce maternal and infants death is life cycle approachment. In that approachment, teenagers are the important part as shown in below chart. This program's stages are the 
deferment of marriage, the increment of public

health clinic (Puskesmas), distribution of blood supplement tablet and reproductive organs health education in schools $[1,2]$.

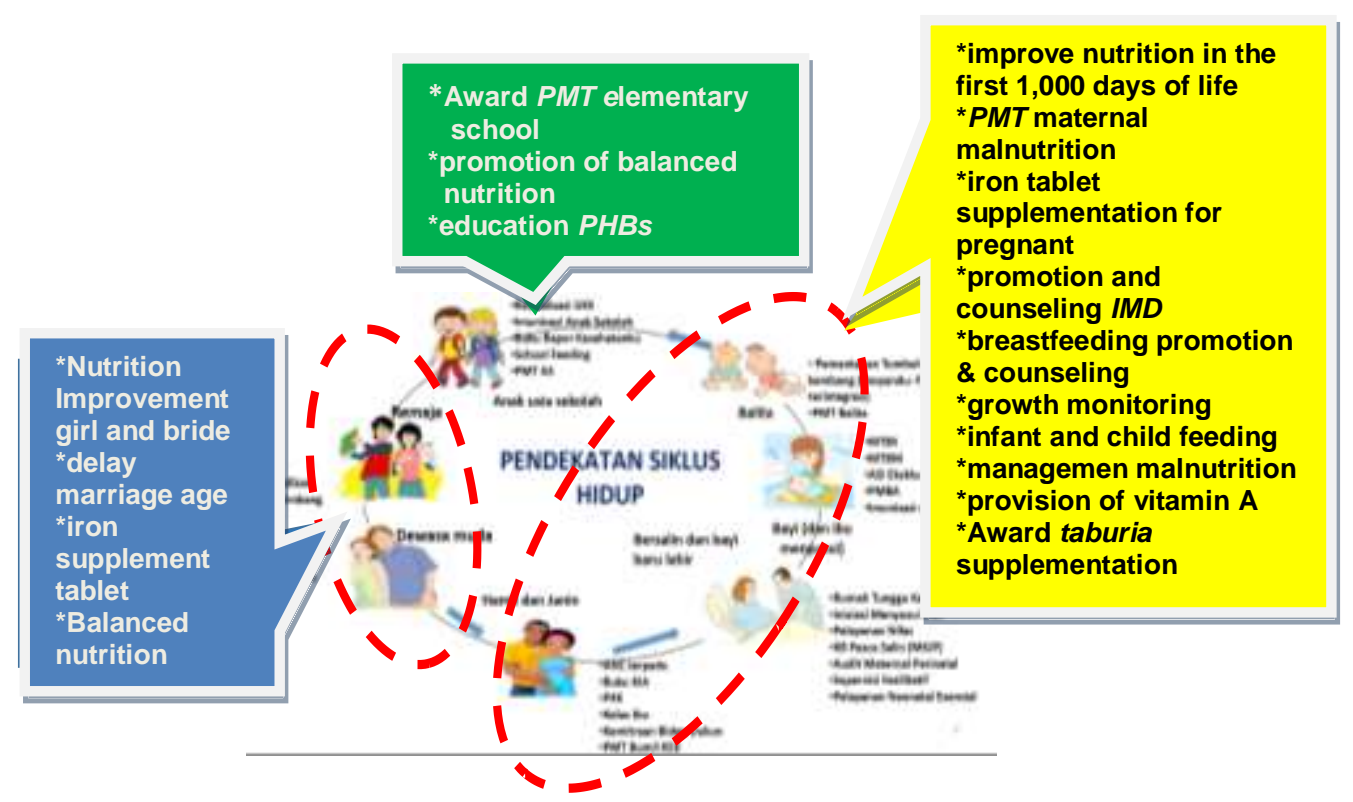

Figure 1. Grafic of life cycle approach Ministry of Health, 2015[2]

The design of the research is observational analytic research by using cross sectional method to answer the research problem, " how much the food consumption pattern and the nutrition status of teenagers effect the hemoglobin degree of the students of SMK?". This research is to support the government program that concerns on the service provided by health service units to teenagers especially the female ones to decrease the mortal of mother in Kupang city. The population target is the students of SMK (vocational school); there are 12 SMK with the total number of students is 4114 . The sampling technique is cluster simple random sampling by using Slovin formula. The cluster to SMK, got 6 SMK in Kupang. The samples got by the formula are 206 persons in 6 SMK. The research took 3 months, started from January to March 2015. The independent variables are food consumption pattern and the nutrition status of the students while the dependent variable is hemoglobin $(\mathrm{Hb})$ degree. The data were then analyzed by using descriptive statistics, Bivariat by counting chi-square test and the Odds Ratio. Multi-variate test by spearman correlation and linear regression test [5.12].

\section{ETHICAL APPROVAL}

In this study ethical approval was going on from goverment provinsion, city Kupang and the institusi of health educational institutions (elementry school).The sdudent as respondent was gave their sign in the kuisioner as an as a sign of approval. There was not special ethic, because it was a cross sectional study, not experiment study. 


\section{RESULTS}

Food consumption pattern covers the amount, frequency and kind of food consumed by 206 students of SMK. Seen from energy needs and the protein consumed, the result showed that energy total under 2125 kilocalories was $93.2 \%$ and protein under 57 gram was $79,6 \%$. The food frequency was $42,3 \%$ of the students whose had their meal less than three times a day. Students who consume 3 to 4 food sorts a day is $79.1 \%$. Nutrition status was measured by Body Mass Index (BMI). Students were BMI under 17 $(13.6 \%)$ and BMI on 17-25 (80\%). The hemoglobin degree was under $12 \mathrm{gr} / \mathrm{dl}$ more in female $(61,6 \%)$ than in male $(38,4 \%)$. The lowest level of hemoglobin was $8,7 \mathrm{gr} / \mathrm{dl}$ in female student and the highest level of hemoglobin was $14,2 \mathrm{gr} / \mathrm{dl}$ in male student. The anemia ratio of female and male teenagers is $4: 3$ [12].
Odd ratio value (risk estimation) was 1.03 with confidence interval 95\% was $0.574-1,855$. It meaned that female students' probability in getting Anemia is 1.03 higher than male students. The odd ratio value found supports the previous description that said the risk of getting anemia was higher in the female students than in the male ones. This anemia tendency in female teenagers is because they have menstruation every month. They also do not care with their nutrition with enough protein, carbohydrates and fats just because they want to get a proportional body. Many of vacasional students were poor family. Their protein intake was less than their needed. Protein is a good food source which functions to change the damaged cells on human's body. By using correlation test by Spearman, the following factors such as gender, energy, protein, food frequency, food sort and hemoglobin degree were analyzed [12], as below.

Table 1. The result of correlation test by Spearman on independent variables and hemoglobin degree

\begin{tabular}{|l|c|c|l|}
\hline Variables & Correlation & Correlation Coefficient & Note \\
\hline Energy*hemoglobin & $\mathbf{0 , 0 1 2}$ & 0,174 & Significant, very weak \\
\hline protein*hemoglobin & $\mathbf{0 , 0 0 1}$ & 0,23 & Significant, weak \\
\hline BMI*hemoglobin & 0,280 & 0,076 & Not significant, very weak \\
\hline Food sort *hemoglobin & 0,188 & 0,092 & Not significant, very weak \\
\hline Food frequency*hemoglobin & 0,383 & 0,061 & Not significant, very weak \\
\hline gender*hemoglobin & 0,917 & 0,007 & Not significant, very weak \\
\hline
\end{tabular}

From the table above, it was concluded that food containing energy and protein had correlated to hemoglobin level of the students. Furthermore, this analysis leads to linear regression test to make a model.
The correlation model resulted between hemoglobin degree $\mathrm{Y}$ and protein is $\mathrm{Y}=0.864$ +0.268 protein. It means if we increase the protein once, the hemoglobin would increase 0.864 point. This result shows that the foods containing protein only can increase the 
hemoglobin of teenagers. Even the energy is also significant, but it is very weak. Protein needed by the body may be found in animal products such as eggs, fish, milk, meat, bird and in vegetables like peas and their products such as tempe and tahu. The protein needs of someone should meet his or her age, weight and activity level. Teenagers who are on growth period need much more protein. Protein need standard is shown by the following formula: protein need (gram)/day $=$ 1.2-1.7 gram/ weight. If a teenager whose weight is $45 \mathrm{~kg}$, his or her protein need is = 54-76.5 gram per day. Intake protein can more than the standar for every man, because protein metabolism is perfect.

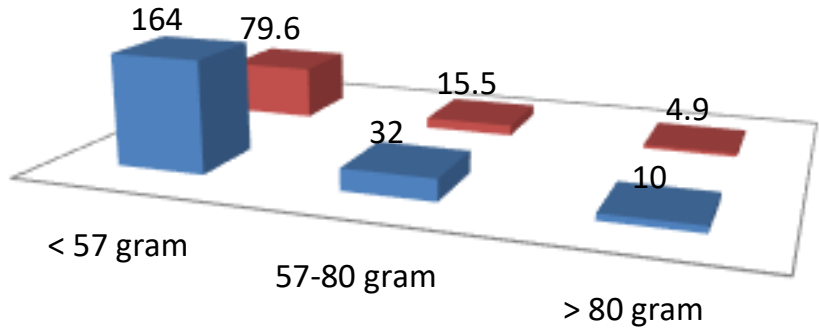

Figure 2: the graphic of protein consumed by the students of SMK in Kota Kupang 2015 [12] The graphic showed 79,6\% students getting protein below standar needed, so they needed require extra protein such as iron tablet.

\section{DISCUSSION}

To decrease maternal mortality rate of Indonesian, it need various strategies. Provinsi NTT on 2009 strategi "revolution mother and child" in a governor regulation [23]. This Program is all deliveries in maternity facilities should be adequate, included Kupang city. Until now, it can reduced Maternal mortality rate a little bit but non infant mortality rate. On 2014, The government of Republic of Indonesia develops the life cycle approach. Teenagers in this case are the future brides of this cycle, they have the nutrient improvement of young female and the future brides, the deferment of marriage, iron supplement tablet given and the campaign of equal nutrient [1,2]. The research found that anemia had suffered the students of SMK in Kupang city especially for the female teenagers $(\mathrm{OR}=1,03)$. There needs urgent intervention from school health program by giving iron supplement tablet to this group of female teenagers $(61,6 \%)$. By conducting this observation, the researcher found that school health program in vocational school just giving counseling on reproductive health without providing with iron supplement tablet. All group of female teenagers with anemia in fact are referred to community Health centers to get the iron supplement tablet [1,2]. Therefore, many school health programs have not implemented provision of iron supplement tablet for teenage school level (SMA/SMK) as 
a routine programs yet. Elucidation on the health of balanced nutrition must be developed. Therefore, the information is not just about reproductive health on youth. The provision of blood supplement tablet is the main action when you found young people with anemia before being referred to the public health clinic to help medical team and officer save teenager's soul. In a study of young female in Denpasar-Bali [19] stated that there is a direct influence between levels of hemoglobin of youth on the ability to study biology $\quad($ Beta $=0,35, \quad \mathrm{t}=3,20$ and $\mathrm{t}$ $(0,02 / 2: 40)=2.02)$.

Protein supplement is important for human body to build cells that have already been damaged and needed in a state of emergency so that they can grow properly [24]. Lack of protein in a long time will lead to the less well of growth, decrease immune system, susceptible to ailment, less in performance and creativity, disruption of improvement in cells and organs [13]. Protein in human body is needed to form these substances such as enzymes and hormones. Female teenagers who is assumed to be a mother of a baby need to pay attention to nutritional status [24]. In accordance with the results of research in Makassar, teenagers with less protein $(46,5 \%)$ get protein from only one source of protein that is fish. The result of that research indicates that the teenagers with daily varied diet, have a normal nutritional status [8]. Young female in Kupang needs to set their habit in consuming protein, in order to get a normal nutritional status. They tend to consume more fish while the protein sources are from beans, eggs, meats and milk [20]. This research found that $65,9 \%$ of young female consumed less than 57 gram of protein each day, while the young male consumed $34,1 \%$. NAR for young female in the of $10-18$ years old are between 56-69 grams, while for young male 56-74 grams. Nutritional Adequacy Rate (NAR) of protein for Indonesians is $\mathbf{5 7}$ grams each day and for the pregnant mom, it needs 20 grams more. Nutritional adequacy rate is a measuring instrument for everyone based on the age, sex, body size and activities [13].

Anemia prevalence in Indonesia is high. Critical anemia in pregnant mom increase the risk of maternal and infants death [23]. Anemia is a condition where someone has less hemoglobin than the normal condition. The ratio of anemia between young male and female of vocational school in Kupang is 3:4, young female with anemia is $61,6 \%$ and young male with anemia is $38,4 \%$ [11]. Young female is more susceptible to have anemia 1,03 times than young male according to the result of this research. Anemia is classified as a problem of lack of micro nutrients, where this problem has bad impact for children and female health for $28,1 \%$ [9, 10] . Malnutrition is commonly happened among the poor society, as it shown in the differences of nutritional status. East Nusa Tenggara is the fifth poorest province in Indonesia (poverty rate is $23,03 \%)[3,20]$.

Students of vocational school are prepared to be a ready-made labor in society. Students from vocational school commonly do not continue their study to university level, as 
they who graduate from public school. Vocational high school students are commonly from the lower middle class society, because their orientation is working after graduate. Therefore, vocational school graduates tend to have an early marriage. Based on the hypothesa, government programs for teenagers should start from vocational school students. It

\section{CONCLUSION AND RECOMENDATIONS}

Young female is risky to suffer from anemia. Both acute and chronic anemia on pregnancy mother is risky to increase the maternal mortality rate. In the fifth part of nine major expectations of the president Jokowi in 2014-2018 is to improve the quality of Indonesia society's life. Furthermore, health ministry descends it in life cycle approach program to reduce the maternal mortality rate. Female students are included in this cycle so it should be concerned by the government, by given iron supplement tablet to all female students in their school.

\section{REFERENCES}

1. Australia Indonesia Partnership for Health Systems Strengthening (AIPHSS ), Ministry of Health. Health Financing and Health Coverage Universe, a Set Policy Memorandum . Jakarta: Australia Indonesia Partnership for Health Systems Strengthening ( AIPHSS ) and the Ministry of Health; 2015 must start from nutrient improvement, provision of blood supplement tablet, campaign of balance nutrient and deferment of marriage. Those aspects in long term period can help to reduce the maternal mortality and infants death rate, if we concern about the bride's nutrient $[1,2]$.

\section{ACKNOWLEDGEMENT}

The number of mother mortality in east nusa tenggara province is still high. The decrease of the number of mother mortality belongs to Jokowi's program on "NAWACITA" and RPJMN of Indonesia heath ministry 2015 - 2019. All government level, start from the province level to the regency one should conduct this program which is operated by Indonesia health ministry through life cycle approach. In this program, teenagers, especially the female ones who live in the poor area get big attention. Nutrition betterment program, giving hemoglobin enrichment tablets, balance nutrition campaign and marriage postpone do not bring immediate effects to the decrease of the number of mother mortality but the long ones.

2. The National Development Planning Agency / Bappenas and Australia

Indonesia Partnership for Health Systems Strengthening ( AIPHSS ). Health Sector Review ( HSR ), set Policy Brief ." Health Development Agenda 2015-2019 . Jakarta: Ministry of Health: 2014

3. The Central Statistics Agency ( BPS ), 2010. The National Census poverty 
figures in Indonesia . Jakarta: The Central Statistics Agency ( BPS ), 2010

4. Family Planning Board $(B K K B N) ; B P S$; Ministry of Health; USAID. Demografie and Health Survey Indonesia 2012 ( SDKI, 2012) . Jakarta: BPS: 2013

5. M. Dahlan Sopiyudin . Statistics for Medicine and Health . Jakarta : Publisher Salemba Medika; 2011.

6. The Ministry of Health. Indonesia Health Profile 2002 Jakarta: Ministry of Health; 2004

7. NTT Provincial Health Office . Health Profile of NTT Provincial 2014. Kupang: NTT Provincial Health Office; 2015

8. Lydia Fanny , Salmiah , Pakhri A. " Substance Intake Level Nutrition and Nutritional Status of High School Students PGRI Maros regency of South Sulawesi " . Makasar:. Media Nutrition , Vol . IX, Issue 1, January-June 2010; p. 34-44

9. Natalia $\mathrm{P}$; Nasution E ; A Siagian. Consumer Behavior and Balanced Nutritional Medan: Status in Teenangers in the Year 2012 SMAN 1 Tarutung. Thesis : USU: 2012

10. Nyoman , I.D.S. Nutritional Status Assessment . Jakarta : EGC; 2002

11. Nugraheni, SA. Info Nutritional Anemia.Semarang: FKM Undip: 2007

12. Pay Frida S. , 2015. Influence of Food Consumption Patterns, Nutritional Status and Hemoglobin $(\mathrm{Hb})$ Against Student Achievement SMK Kota Kupang . Kupang: Thesis : Undana, Kupang
13. Regulation of the Minister of Health of Indonesia Number 75 Year 2013 On The Nutrition Adequacy Score advisable To Indonesia. Jakarta : Ministry of Health RI : 2013

14. Regulation of the Minister of Health No. 25 of 2014 on Child Health Efforts . Jakarta : Ministry of Health RI; 2014

15. PKBI NTT. Survey of Youth in Kota Kupang . Kupang : PKBI, NTT; 2006

16. Body Of Research \& Development Of Health Ministry. Basic Health Research. Jakarta: 2010

17. Body Of Research \&Development Of Health Ministry. Basic Health Research. Jakarta: 2013

18. Sastroasmoro. Fundamentals of Clinical Research Methodology . Jakarta : Rineke : 2010

19. Sukawana I.Wayan.Effects of Nutritional Status, Hemoglobin \& Blood Sugar Against Learning Outcomes Biology. Denpasar: Thesis ;2007

20. Supariasa. Nutritional Status Assessment . Jakarta : EGC; 2009

21. Soetjiningsih. Growth . Surabaya: EGC ; 2002

22. UNICEF - Indonesia . Indonesia Annual Report 2012

23. NTT Provincial Health Departmen. Guidelines for Maternal and Child Health Revolution. Kupang : NTT Provincial Health Departmen, 2009

24. Boyle M. Emergencies In Childbirth : Midwife Pocket Book. Jakarta : EGC; 2007 